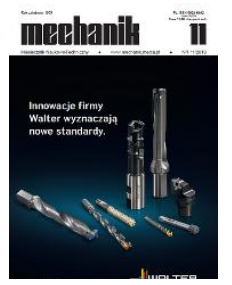

How to cite this article:

Author: Ryszard Wolny

Title of article: „The process of regeneration of the high-pressure turbine cylinder”

Mechanik, No. 11 (2019)

DOI: https://doi.org/10.17814/mechanik.2019.11.96

\title{
The process of regeneration of the high-pressure turbine cylinder
}

\section{RYSZARD WOLNY *}

Dr inż. Ryszard Wolny, rwolny@itm.pcz.pl, https://orcid.org/0000-0003-2013-7832 - Instytut Technologii Mechanicznych, Wydział Inżynierii Mechanicznej i Informatyki Politechniki Częstochowskiej, Częstochowa, Polska

The process of regeneration of the cylinder of a high-pressure turbine being a subassembly of a $360 \mathrm{MW}$ power block was presented. Criteria that qualify the cylinder for regeneration were discussed. Machining operations with the description of machine tools and special devices were characterized. In order to ensure high-quality requirements cutting parameters for selected operations were optimized.

KEYWORDS: turbine cylinder, machining operations, regeneration, optimization

\section{Introduction}

The high-pressure turbine cylinder consists of two cast parts [1-4]. Cylinder is made of alloy cast steel for operation in higher temperature L20M [5]. The weight of upper part of body is 16 tonnes, while the weight of the bottom part - 17 tonnes. Cylinder general view is shown in fig.1.

The basic criterion of the selection of high-pressure cylinder is tightness. Lack of tightness means a decrease of turbine power. Due to turbine operating parameters, i.e. live steam pressure 17.6 MPa and secondary steam 4.0 $\mathrm{MPa}$ and superheated steam temperature $535^{\circ} \mathrm{C}$, there is potential risk to public health.
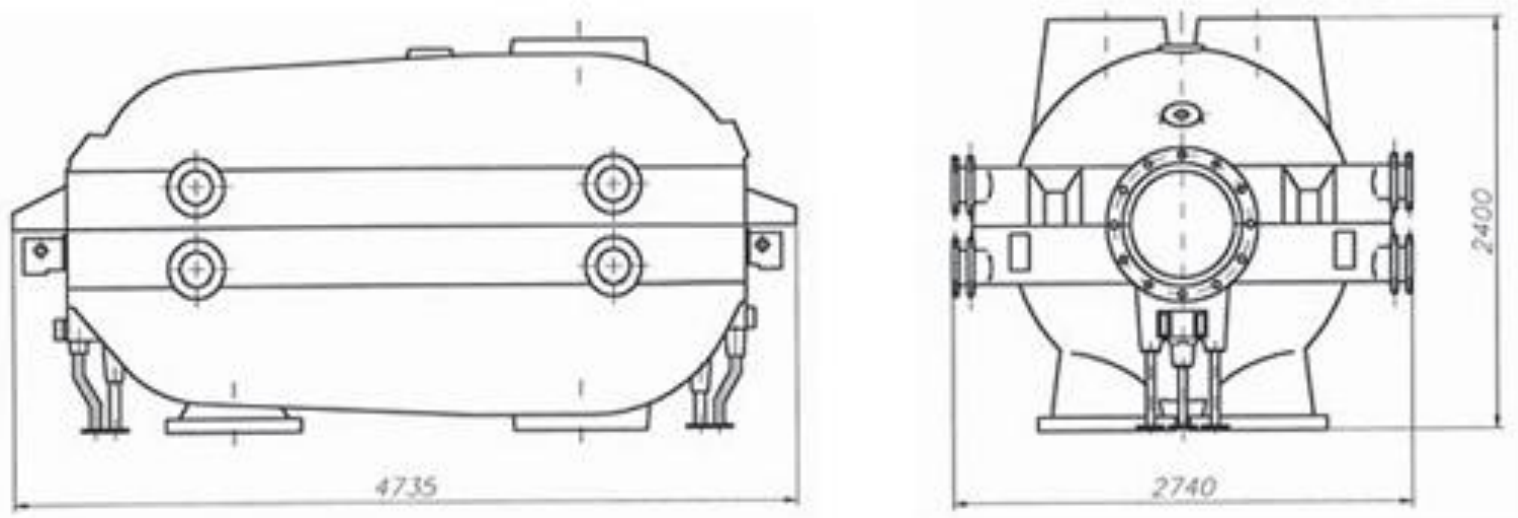

Fig. 1. Turbine body [6]

The body tightness means adhesion of its two halves. A gap between body parts, loosely laying on each other, at any place may not exceed $0.03 \mathrm{~mm}$. Presence of machining marks and transversal cracks running from outer to inner edge of parting surface is unacceptable. The high flatness of parting surface, adherence marks constituting at least $90 \%$ of strips width of interface between body halves and surface roughness $R_{\mathrm{a}} \leq 0.63 \mu \mathrm{m}$ is required.

The body may not have moulding defects or cracks. To ensure rotor shaft leakage, apart from parting surface, it is important concentricity of holes for stuffing boxes. Tightness of the connected body halves is suitable during the water tests for pressure $7.7 \mathrm{MPa}$, with water temperature $20^{\circ} \mathrm{C}$ during 20 hours. 
Body repairs schedule determine, that intermediate repair is carried out after a 25,000 hours of turbine use, general repair after 50,000 working hours [4]. Body is subject to significant deformations during operation. Parting surface deformation comes to $2.0 \mathrm{~mm}$, and circular deviations of holes for stuffing boxes sometimes amount to $0.8 \mathrm{~mm}$. The main task of regeneration process of the high-pressure cylinder is to restore original accuracy parameters, i.e. dimensions coming within the requested tolerance and specified value of shape and position deviations.

\section{Turbine body regeneration process}

The operation during turbine body regeneration process was performed in the following sequence:

- machining surfaces representing body parting surface,

- machining of receiving bores for stuffing-box and centering ring and external face surfaces,

- machining of hole for thermocouple in the upper part and holes in the lower part,

- machining of countersinks for sleeve nut in the upper part of body,

- machining of slots in the body rear mounting foot and holes in front mounting foot,

- millings validation for internal body suspension in the lower part,

- flange front surfaces validation in both body parts,

- holes boring for conical pins

- conducts of slots body-support validation

- validation of holes face surfaces for eccentric slots in lower body part,

- validation of steam pipeline flanges in lower body part.

Turbine body regeneration was divided into six stages:

- machining of upper part parting surface,

- machining of lower part parting surface and reductions for external body,

- parting surfaces matching,

- receiving bores for stuffing-box and holes for conical pins machining,

- machining of upper part after rotation,

- machining of lower part after rotation.

\section{Parting surface machining}

Parting surface mechanical machining (fig. 2) carried out on boring and milling machine W200G from Skoda [7]. According to the manufacturer guaranteed machine tool geometric accuracy for the new machine is $0.26 \mathrm{~mm}$. The first model tests of both body parts machining allowed to obtain the gap in parting surface equal to $0.30 \mathrm{~mm}$. A result of several dozen tests, took place over 11 months was the parting surface accuracy in range of $0.07 \div 0.09 \mathrm{~mm}$.

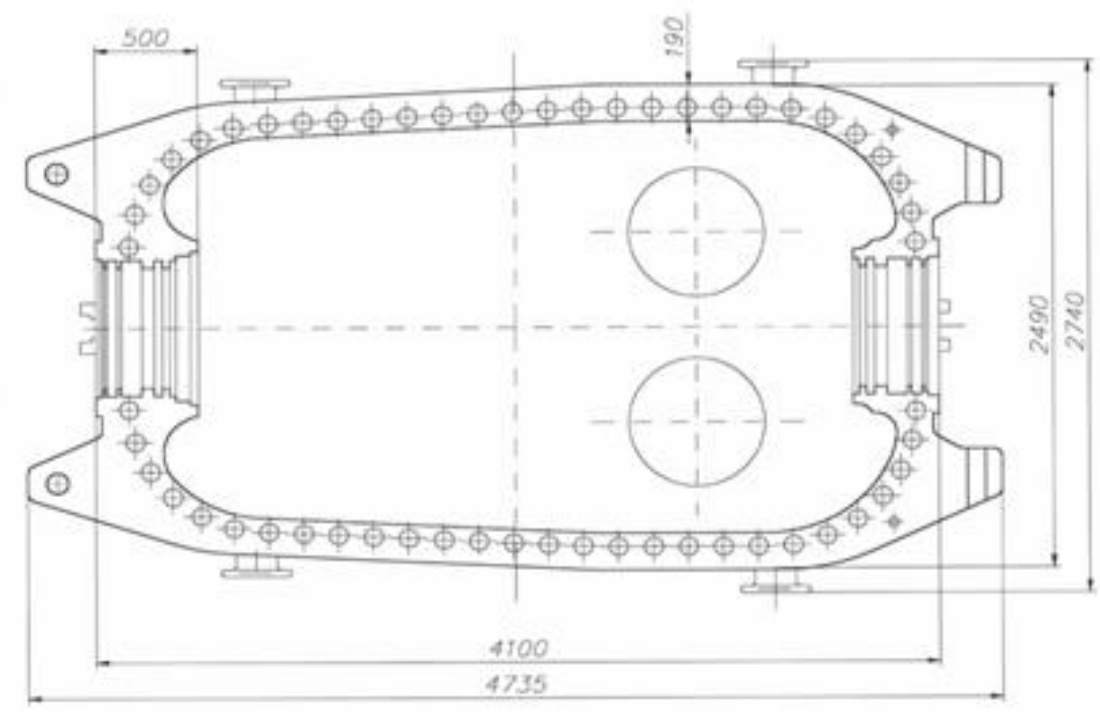

Fig. 2. Plane of the upper part of the turbine body [6] 
Satisfactory test outcomes is the result of numerous attempts to body setting and fixing on the machine tool table and optimisation of tool selection and cutting parameters for roughing and finishing milling procedure [8-10]. The result of properly completed manual finishing machining $[11,12]$ was final precision of surface fitting in body parting surface.

\section{The upper part of body machining}

After the first overview of provided upper body part, the detail is set on rotary table of drilling and milling machine in order to determine the possible damages, i.e. fractures, stratifications and casting defects. Precise determination is carried out using supports regulated by hydraulic actuators ENERPAC [13]. Checking the body settings on the rotary table is done using dial gauge with an accuracy of $0.01 \mathrm{~mm}$, mounted on the machine spindle. Measurement of parting surface flatness and measurement of reductions for slots and holes in body foots were the basis for determination of allowance value for roughing machining by the supervision inspector. This allowance value should be defined in relation to the maximum measured point on parting surface.

Roughing milling of body parting surface was carried out using two swivel angle head (fig. 3) witch mounted sanding head $\varnothing 160$ TPAK16012 by Sandvik [14]. Thickness control of machined layer and checking of real parting surface reduction have created the basis for determination the allowance value for finishing machining by the supervision inspector.

Finishing milling was carried out with the same tools, with cutting parameters ensuring parting surface roughness $R_{\mathrm{a}} \leq 0.8 \mu \mathrm{m}$.

The technological challenge was manual finishing machining of parting surface by running-in until obtained roughness $R_{\mathrm{a}} \leq 0.63 \mu \mathrm{m}[11,12]$. After completely removing the machining marks, was necessary to smooth over running-in surface from reference plate. On smoothed surface should not be present cracks and reductions perpendicular to outline edge of parting surface presenting hazards due to outlet steam during turbine operation.

In order to proper performance of manual finishing machining, has to be designed and carried out special software. Manual finishing machining of the upper part of body took 48 hours and was performed on a continuous basis by two changing teams of 10 employees.

A positive result of parting surface flatness and roughness control was the basis for removing of machined upper part of body from drilling and milling machine and for parting surface protection against damage.

In the case of lower body part individual operations of the technological process carried out in a similar way.

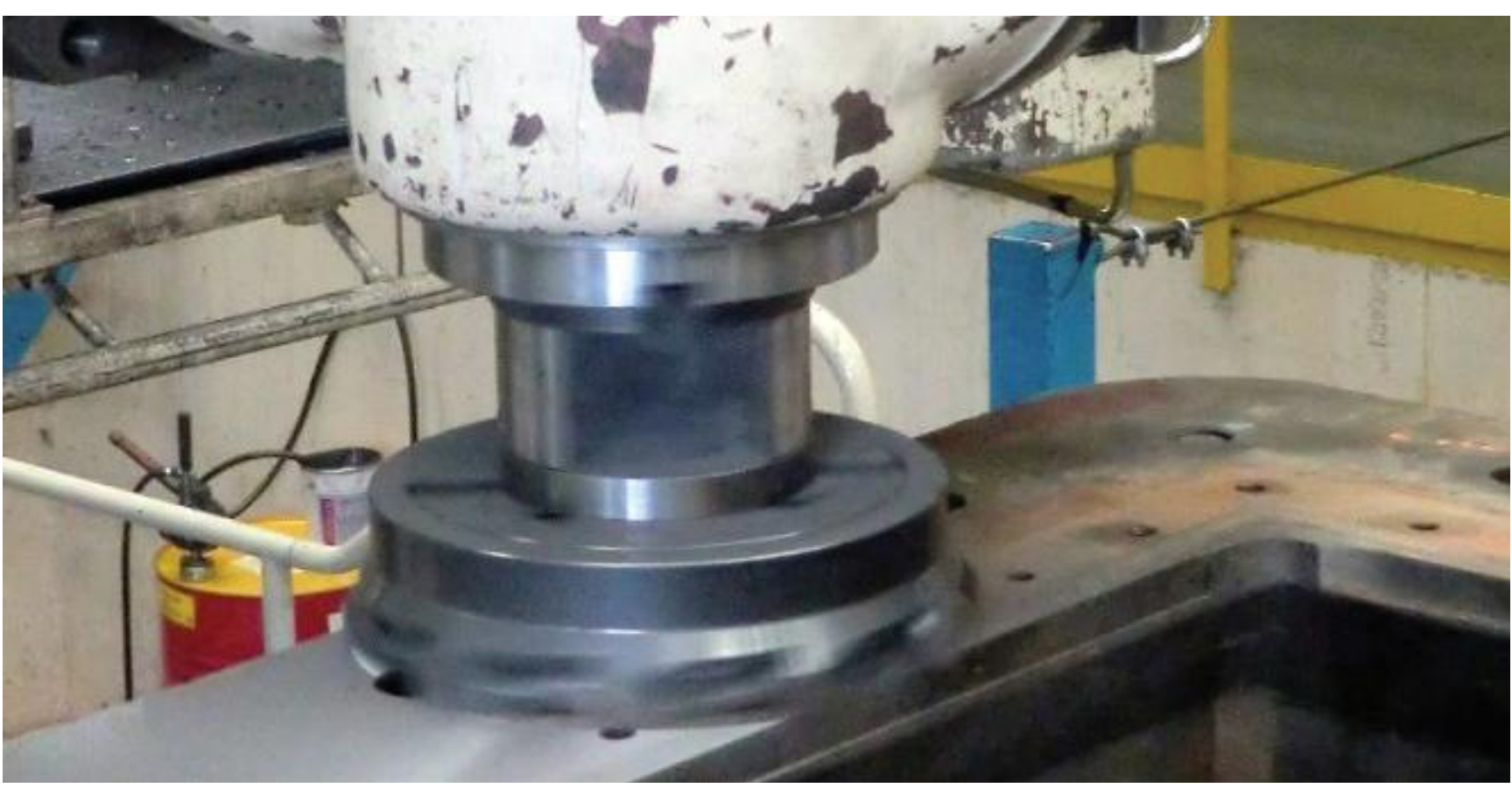

Fig. 3. Two-angle head with mounted sanding head $\varnothing 160$ by Sandvik during machining [6]

After machining operations of upper and lower body parts were carried out following technological operations: 
- putting the upper body part on the lower part; in unscrewed condition there should be no gap between them $\geq 0.03 \mathrm{~mm}$,

- screwed every second stud to check adhesion of parting surfaces (for ink) according to the delivery conditions,

- loosening of studs and removal of body upper part to check adhesion and make corrective changes,

- obtaining from supervision inspector authorisation to further machining.

\section{Machining of receiving bores for stuffing boxes}

Setting turbine body on rotary table of drilling and milling machine W200G and bearing of boring bar (length $5400 \mathrm{~mm}$ ) for boring of holes for stuffing boxes and centering ring are shown in fig. 4. Concentricity of boring bar bearing with accuracy of $0.02 \mathrm{~mm}$ provided laser measuring instrument FIXTUR LASER T220 [15]. The measuring system head with laser transmitter (fig. 5) was mounted in spindle of drilling and milling machine using special handle.

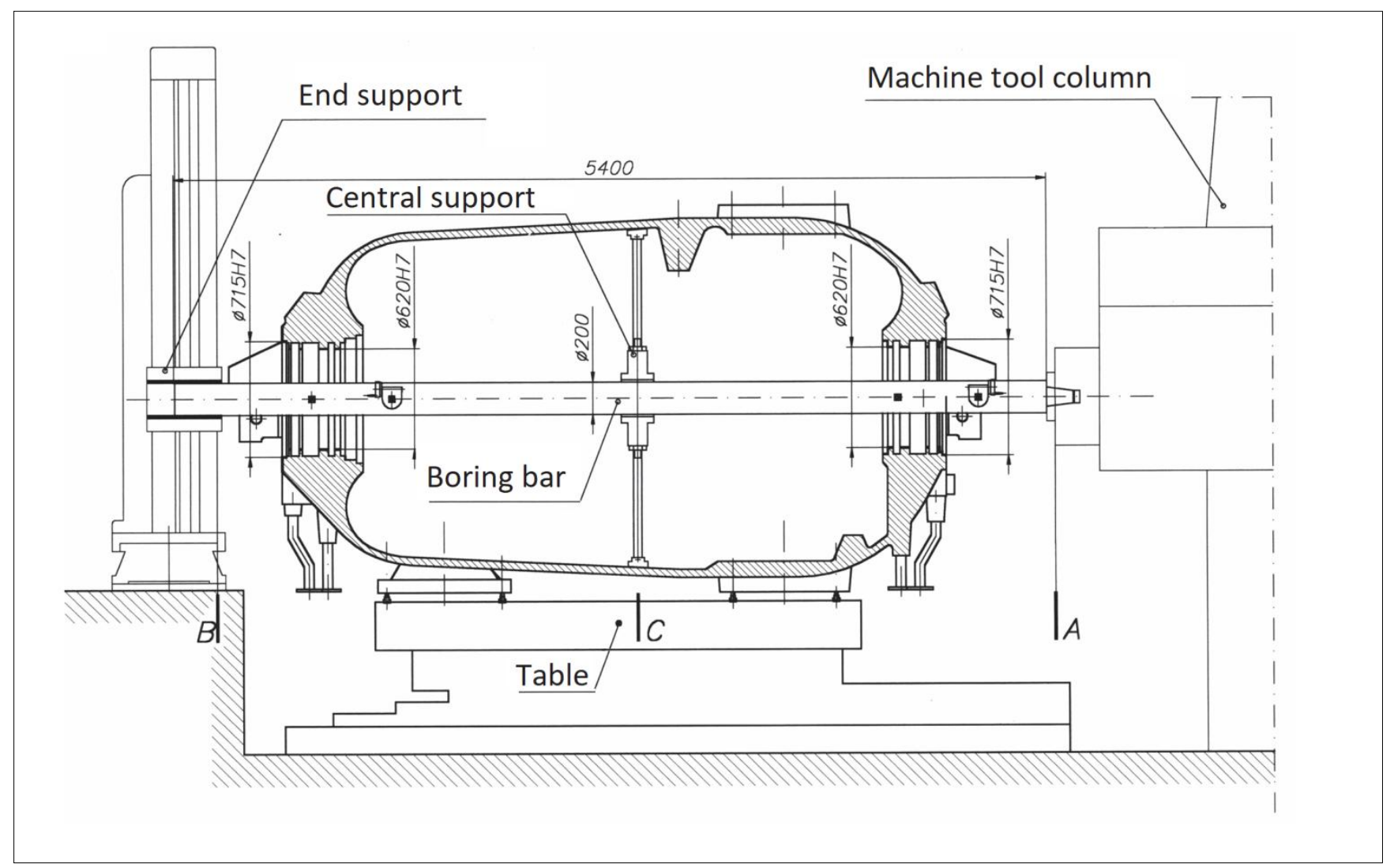

Fig. 4. Setting a boring bar for machining holes for stuffing boxes [6]

In the final support was mounted readout receiver in handle with three supports fitting to hole diameter of bearing sleeve in machine tool support. Concentricity with accuracy of $0.02 \mathrm{~mm}$ could be obtained due to spindle rotation and displacement correction in particular axes. In order to correction of deflection for such a long boring bar was used three-arm middle support placed inside of machined body.

For boring of holes for stuffing boxes and centering ring was used universal boring head Vhu 125 from NAREX [16].

The head has default range of diameters machining $\varnothing 12 \div 650 \mathrm{~mm}$, but due to special attachment was possible to boring of holes for centering ring $\varnothing 715 \mathrm{~mm}$ and flanges facing per diameter $\varnothing 800 \mathrm{~mm}$.

For the boring operations were used shank tool for turning with insert CNMG 190612 [14]. Cutting parameters have been optimised to meet the following machining quality requirements:

- holes accuracy class H7,

- face planes run-out $\leq 0.02 \mathrm{~mm}$,

- holes radial run-out $\leq 0.03 \mathrm{~mm}$,

- receiving bores for stuffing-box concentricity $\leq 0.04 \mathrm{~mm}$,

- surface roughness $R_{\mathrm{a}} \leq 1,6 \mu \mathrm{m}$. 
Accuracy parameters for new body specified by the manufacturer have been achieved after completing all machining operations. Consequently, by the regeneration was restored its original operational properties.

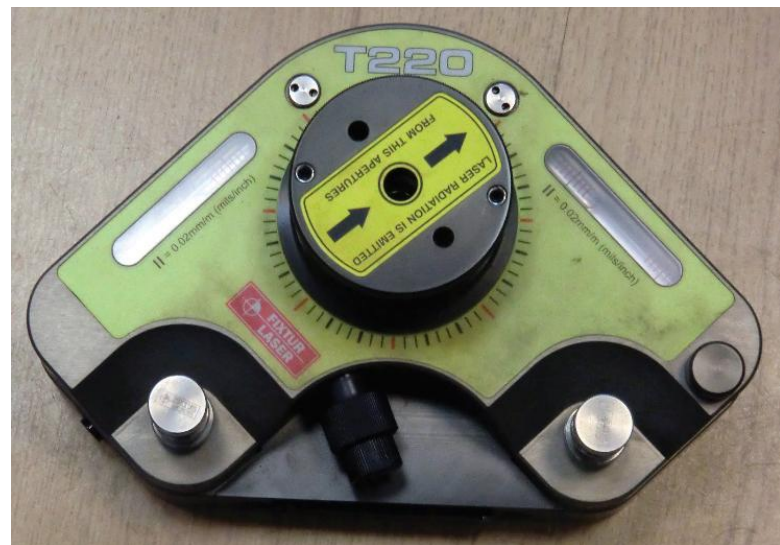

Fig. 5. FIXTUR LASER T220 laser head with transmitter [6]

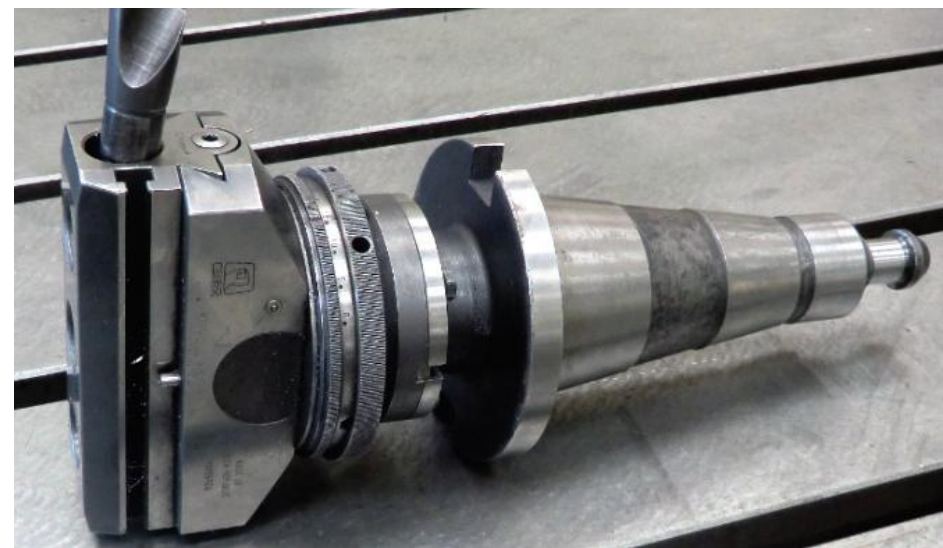

Fig. 6. Universal boring head Vhu 125 by NAREX company with a boring knife mounted [6]

Once the high-pressure turbine cylinder has been transported in assembly place, first the lower body part was set up and mounted to the ground. The next stages were installation of turbine rotor inside the body, assembly in the place of stuffing boxes supports and the upper body part mounting. For correct fixing of both body parts was used two conical dowels $\varnothing 48 \times 558 \mathrm{~mm}$. Initial bolting of two body halves was carried out by studs M100 × $6 \times 800$ and nuts M100 $\times 6$ made from alloyed steel 21HMF, 60 pieces in total. Final bolting of two body halves took place after heating the fastening elements, which was studs and nuts. Assembly procedures ended at adding the thermocouple and control and measurement equipment.

\section{Summary}

The above technological process apply to regeneration of the high-pressure turbine cylinder after 50 thousand working hours in a power block with power $360 \mathrm{MW}$ at the lignite-fired power plant The basis machining operations and manual finishing machining are characterized. All works have been completed at the faculty of mechanical engineering of the power plant. Available machinery, modern tools and special equipment application have created the basis for restoration of body original operational properties.

\section{LITERATURA}

[1] Szulc P. „Aktualne kierunki rozwoju energetyki”. Wrocław: Politechnika Wrocławska, 2012.

[2] Chmielnik T. „Technologie energetyczne”. Warszawa: WNT, 2008.

[3] Laudyn D. „Elektrownie”. Warszawa: WNT, 1995.

[4] www.zre.com.pl (access: 15.06.2019).

[5] PN-EN 10213: 2008 - Odlewy staliwne do pracy pod ciśnieniem, 2008.

[6] Olczak D. „Regeneracja korpusu zewnętrznego turbiny wysokoprężnej”. Praca dyplomowa inżynierska. Częstochowa: Instytut Technologii Mechanicznych, Politechnika Częstochowska, 2017.

[7] www.skoda-machine-tool.czech-trade.pl (access: 15.06.2019).

[8] Olszak W. „Obróbka skrawaniem”. Warszawa: WNT, 2008.

[9] Przybylski L. „Strategia doboru warunków obróbki wspótczesnymi narzędziami. Toczenie, wiercenie, frezowanie". Kraków: Politechnika Krakowska, 2000.

[10] Rychlik K., Jastrzębski M., Pabich M. „Adaptacja współrzędnościowej obrabiarki na potrzeby zadaniowej obróbki korpusów turbin”. Technologia i Automatyzacja Montażu. 4 (2009): 31-34.

[11] Barylski A. „Obróbka powierzchni płaskich na docierarkach”. Gdańsk: Wydawnictwo Politechniki Gdańskiej, 2013.

[12] Stahli A.W. "The technique of lapping”. Pieterlen/Biel, 2013.

[13] www.enaprac.com (access: 15.06.2019).

[14] www.sandvik.coromant.com/pl (access: 15.06.2019).

[15] www.fixturlaser.com (access: 15.06.2019).

[16] www.narexmte.cz (access: 15.06.2019). 